\title{
ENVIRONMENTAL KUZNETS CURVE HYPOTHESIS IN SELECTED EU COUNTRIES: KYOTO EFFECT
}

\author{
Cuma Bozkurt ${ }^{1}$ \\ İlyas Okumuş²
}

Received: April 29, 2019 / Revised: July 29, 2019/ Accepted: October 11, 2019

(C) Association of Economists and Managers of the Balkans, 2019

\begin{abstract}
The purposes of this study is to investigate the relationship between per capita CO2 emissions, per capita energy consumption, per capita real GDP, the squares of per capita real GDP, trade openness and Kyoto dummies in selected 20 EU countries over the periods from 1991 to 2013 in order to analyze the connection between environmental pollution and Kyoto Protocol using Environmental Kuznets Curve (EKC) framework. According to EKC hypothesis, there is an inverted-U shape relation between environmental pollution and economic growth. Generally, the relationship between environmental pollution, per capita GDP and energy consumption has been analyzed for testing EKC hypothesis. In this study, it is used dummy variable to analyze the effects of Kyoto protocol on environmental degradation in the context of EKC hypothesis model. The dummy variable indicates Kyoto Protocol agreement year 2005. The results show that there is long run cointegration relationship between CO2, energy consumption, GDP growth, and the squares of GDP growth, trade openness and Kyoto dummy variable. Energy consumption and GDP growth increase the level of CO2 emissions. On the contrary, Kyoto dummy variable decreases CO2 emissions in EU countries. In addition, the results reveal that the squares of per capita real GDP and trade openness rate are statistically insignificant. As a result of analysis, the inverted-U shape EKC hypothesis is invalid in these EU countries over the periods from 1991 to 2013 .
\end{abstract}

Keywords: Environmental Kuznets Curve, Kyoto Protocol, EU countries

\section{JEL Classification Q01 · Q56}

This paper was presented at the Fifth International Scientific Conference on Knowledge Based Sustainable Development - ERAZ 2019 - May 23, Budapest, Hungary, www.eraz.org.rs

Cuma Bozkurt

cbozkurt@gantep.edu.tr

1 Department of International Trade and Logistics, Faculty of Economics and Administrative Sciences, Gaziantep University, Turkey

2 Department of Public Finance, Faculty of Economics and Administrative Sciences, Mustafa Kemal University, Turkey 


\section{INTRODUCTION}

In recent years, one of the most frequently discussed global issues has been environmental degradation in the context of global warming and climate change. It is the main cause of global warming and climate change that rapid rise in gases that causes greenhouse effect in the atmosphere. The main gas causing greenhouse effect is carbon dioxide emissions (CO2) that emitted into atmosphere by using fossil fuels such as petroleum, coal and natural gas. With the advents of Industrial Revolution, economic development is first target for many countries. This aim has increased energy demand and this need has been met greatly from the fossil fuels. Because of climate change and global warming, the search for relationship between environmental pollution, economic growth and energy use has been investigated in the framework with EKC hypothesis (Bozkurt et al, 2016:59).

Kyoto Protocol as a global policy in order to reduce CO2 emissions. The targets for the first commitment period of the Kyoto Protocol cover emissions of the six main greenhouse gases. One of them and the most important is CO2. The 15 States who were EU members in 1997 when the Kyoto Protocol was adopted, took on that $8 \%$ target that will be redistributed among themselves, taking advantage of a scheme under the Protocol known as a "bubble", whereby countries have different individual targets, but which combined make an overall target for that group of countries. The EU has already reached agreement on how its targets will be redistributed (Kyoto Protocol, 1997).

In this study, the relationship between per capita $\mathrm{CO} 2$ emissions, per capita energy consumption, per capita real GDP, the squares of per capita real GDP, trade openness and Kyoto dummies over the periods from 1991 to 2013 in order to analyze the connection between environmental pollution and Kyoto Protocol using Environmental Kuznets Curve (EKC) hypothesis for selected 20 EU countries.

The rest of the paper is as following; Second section involves the literature review, Third section describes the data, model, methodology and empirical findings, Fourth section presents the conclusion and policy implications of the study.

\section{LITERATURE REVIEW}

Kuznets (1955) predicted that the changing relationship between per capita income and income inequality is an inverted-U shaped curve. Kuznets Curve says that as per capita income increases, income inequality also increases at first and then starts declining after a turning point. In the 1990s, Kuznets Curve hypothesis is started to apply the relationship between environmental quality and per capita income. In recent years, Environmental Kuznets curve hypothesis is analyzed intensively due to increasing environmental incidents and economic crisis. The hypothesis was firstly tested by Grossman and Kruger (1991). The inverted-U put forward by Grossman and Krueger (1991) in 1991 regarding the relationship on economic growth and environmental quality was named as the Environmental Kuznets Curve (EKC) by Panayotou (1993) and has been continued from then on (Chen, 2007:02). According to EKC, after economic growth reaches a certain level, it will remedy the environmental effects of the initial stages of economic development and compensate for it (Sun, 1999:692).

Coondoo and Dinda (2002), Dinda (2004), Luzzati and Orsini (2009), Halicioglu (2009), Acaravci and Ozturk (2010) studies provide an extensive literature on EKC hypothesis. In these studies, the 
relationship between environmental pollution and economic growth was tested. In addition, the relationship between environmental degradation, economic growth and energy consumption was analyzed by Richmond and Kaufman (2006), Soytas et al. (2007), Zhang and Cheng (2009), Halicioglu (2009), Apergis and Payne (2009, 2010), Ozturk and Acaravci (2010), Acaravci and Ozturk (2010), Pao and Tsai (2011), Ozturk and Uddin (2012) (Bozkurt et al, 2016:60).

Lapinskiene et al. (2014) explored the relationship between economic growth and greenhouse gas emissions by applying time series analysis for EU-27, Norway and Switzerland for 1995-2010 periods. The results supported inverted U-shaped EKC is valid for EU countries. Bölük and Mert (2014) used panel data analysis to investigate the relationship between economic growth, energy consumption and CO2 emissions in 16 EU countries for 1990-2008 periods. The result of the study showed that the inverted U-shaped EKC hypothesis is valid for EU countries. Sterpu et al. (2018) looked at the relationship between economic growth, energy consumption, greenhouse gas emissions, energy consumption and renewable energy consumption with an aim to test the validity of the EKC hypothesis for 28 countries of EU for 1990-2016 periods. The results validate inverted U-shaped EKC hypothesis.

\section{DATA AND MODEL}

This study aims to investigate the relationship between carbon emissions, real GDP, the square of the real GDP, energy consumption and Kyoto Protocol in selected 20 EU countries (Austria, Belgium, Bulgaria, Cyprus, Denmark, Finland, France, Germany, Greece, Hungary, Ireland, Italy, Luxembourg, Malta, Netherlands, Portugal, Romania, Spain, Sweden and the UK) for the period of 1991-2013. Following EKC models, CO2 defined as a function of energy consumption, real GDP, the squares of the real GDP, trade openness and Kyoto dummy variable. Based on the studies in the literature, the panel version of model can be shown as follows:

$$
\ln C O_{2 i t}=\beta_{0 i}+\beta_{1 i} \ln G D P_{t}+\beta_{2 i} \ln G D P_{t}^{2}+\beta_{3 i} \ln E_{t}+\beta_{4 i} \ln T R_{t}+\beta_{5 i} \ln D U M_{t}+\varepsilon_{i t}
$$

where $\ln C O, \ln G D P, \ln G D P^{2}, \ln E, \ln T R, \ln D U M$ indicate the natural logarithms of carbon emissions measured in metric tons per capita, the GDP per capita measured in millions of constant 2005 US dollars, square of the GDP per capita measured in millions of constant 2005 US dollars, energy use ( $k t$ of oil equivalent), trade openness rate peroxided by the ratio of exports plus imports to GDP and Kyoto dummy variable for Kyoto Protocol agreement year 2005, respectively.

\section{METHODOLOGY AND EMPIRICAL RESULTS}

The empirical analysis consists of three steps. In the first step, stationarity properties of the variables were analyzed using with panel unit root tests such as LLC unit root test developed by Levin et al. (2002) and IPS unit root test developed by Im et al. (2003). The null hypothesis of both test indicate unit root process. The results of LLC and IPS unit root tests are shown in Table 1. At a first glance, the null of unit root can't be rejected clearly at $1 \%$ percent level. When the difference operator is used, the null of unit root can rejected strongly and all variables become stationary. The variables are integrated of order one therefore it seems there is possible long-run relationship between variables. 
Table 1. LLC and IPS unit root tests results

\begin{tabular}{|c|c|c|c|c|}
\hline & LLC & & IPS & \\
\hline Variable & Constant & Constant\&Trend & Constant & Constant\&Trend \\
\hline $\operatorname{lnCO}$ & $2.5307[0.9943]$ & $2.0970[0.9820]$ & $2.2096[0.9864]$ & $2.6664[0.9962]$ \\
\hline InGDP & $-4.4864[0.0000]$ & 4.5650 [0.9999] & $0.2203[0.5872]$ & 6.6408 [0.9999] \\
\hline $\operatorname{lnGDP}^{2}$ & $-4.0768[0.0000]$ & $5.3220[0.9999]$ & $5.6301[0.9999]$ & $1.0261[0.8476]$ \\
\hline $\ln E$ & $-0.8956[0.1852]$ & $2.5520[0.9946]$ & $-0.6509[0.2575]$ & 4.2856 [0.9999] \\
\hline $\ln T R$ & $-2.5465[0.1568]$ & $-3.7858[0.0087]$ & $0.4644[0.6778]$ & $-3.1498[0.0031]$ \\
\hline$\Delta \ln \mathrm{CO}_{2}$ & $-14.8124[0.0000]$ & $-15.9850[0.0000]$ & $-14.1041[0.0000]$ & $-15.0935[0.0000]$ \\
\hline$\Delta \operatorname{lnGDP}$ & $-6.8675[0.0000]$ & $-9.1967[0.0000]$ & $-6.2628[0.0000]$ & $-7.0342[0.0000]$ \\
\hline$\Delta \operatorname{lnGDP}{ }^{2}$ & $-6.9317[0.0000]$ & $-9.2195[0.0000]$ & $-6.3270[0.0000]$ & $-6.9727[0.0004]$ \\
\hline$\Delta \ln E$ & $-15.1086[0.0000]$ & $-15.7210[0.0000]$ & $-13.3288[0.0000]$ & $-15.5852[0.0000]$ \\
\hline$\Delta \ln T R$ & $-18.5964[0.0000]$ & $-15.8828[0.0000]$ & $-15.6835[0.0000]$ & $-13.8604[0.0000]$ \\
\hline
\end{tabular}

$\Delta$ is the first difference operator. The maximum lag lengths were selected automatically using with Schwarz Information Criteria. Numbers in brackets are $p$-values. Newey-West bandwidth selection with Bartlett kernel is used for LLC test. Numbers in brackets are $p$-values.

In order to examine the long-run relationship between variables, the panel cointegration test developed by Pedroni (1999) is utilized. Pedroni (1999) developed seven statistics to analyze the possible long-run relation and the test which is based on estmation of Eq 1. with estimation of $\delta_{i} \varepsilon_{i t-1}+\sum_{k=1}^{K_{i}} \delta_{i k} \Delta \varepsilon_{i t-k}+v_{i t}$ regression model. The null hypothesis of test indicates that there is no cointegration between variables.

The panel cointegration test results are presented in Table 2. The results reveal that the null of no cointegration can be rejected for the model. Therefore, it can be said that the carbon emissions $\left(\mathrm{CO}_{2}\right)$, real GDP, the squares of real GDP, energy consumption, trade openness and Kyoto dummy variable are cointegrated.

Table 2. Pedroni cointegration test results.

\begin{tabular}{|c|c|c|}
\hline Test & Constant & Constant and trend \\
\hline Panel $\boldsymbol{v}$-statistic & -0.1222 & $1.6247^{*}$ \\
\hline Panel $\boldsymbol{\rho}$-statistic & 0.3500 & 0.2097 \\
\hline Panel $\boldsymbol{P P}$-statistic & $-3.2851^{* * *}$ & $-7.8104^{* * *}$ \\
\hline Panel $\boldsymbol{A D F}$-statistic & $-3.6341^{* * *}$ & $-8.4791^{* * *}$ \\
\hline Group $\boldsymbol{\rho}$-statistic & 1.9272 & 2.0494 \\
\hline Group $\boldsymbol{P P}$-statistic (non-parametric) & $-3.5891^{* * *}$ & $-8.6075^{* * *}$ \\
\hline Group $\boldsymbol{A D F}$-statistic (non-parametric) & $-4.2727^{* * *}$ & $-8.2637^{* * *}$ \\
\hline
\end{tabular}

$*, * *$ and $* * *$ indicates statistically significance at 10,5 and 1 percent level, respectively.

The next step is to examine the long-run coefficients of cointegrated variables. The long-run coefficients of variables are estimated with fully modified ordinary least squares (FMOLS) developed by Pedroni (2000).

The estimation of FMOLS can be constructed as $\hat{\beta}_{G F M O L S}=N^{-1} \sum_{i=1}^{N} \beta_{F M O L S}$ where $\beta_{F M O L S}$ is ac-
quired from individual FMOLS estimation of Eq 1 . 
Table 3. Panel FMOLS estimation results

\begin{tabular}{|c|c|c|}
\hline Variables & Coefficients & t-istatistic \\
\hline $\operatorname{lnE}$ & $1.2126^{* * *}$ & 31.7020 \\
\hline $\operatorname{lnGDP}$ & $0.7708^{* * *}$ & 19.5742 \\
\hline $\operatorname{InGDP}^{2}$ & 0.0233 & 0.7691 \\
\hline $\ln$ TR & -0.0398 & -0.9069 \\
\hline DUM & $-0.1186^{* *}$ & -2.3195 \\
\hline
\end{tabular}

$*, * *$ and $* * *$ indicates statistically significance at 10,5 and 1 percent level, respectively.

The results of panel group FMOLS estimation are reported in Table 3. The panel group FMOLS estimation results indicate that the increase in energy consumption by $1 \%$ will increase $\mathrm{CO}_{2}$ emissions by $1.2126 \%$. The increase in economic growth by $1 \%$ will increase carbon dioxide emissions by $0.7708 \%$. The results also showed that Kyoto dummy variable has a negative effect on $\mathrm{CO}_{2}$ emissions. On the other hand, the coefficients of the square of real GDP and trade openness are statistically insignificant. According to these results, the EKC hypothesis is invalid for the selected EU countries spanning the period from 1991 to 2013.

\section{CONCLUSION}

The aim of this study is test the impact of the economic growth, energy consumption, trade openness and Kyoto Protocol on $\mathrm{CO}_{2}$ emissions in selected 20 EU countries for the period of 1991-2013 with the context of the EKC hypothesis. It is utilized LLC and IPS panel unit root tests, Pedroni cointegration test and panel FMOLS estimation test.

The test results indicate that there is a long-term relationship between carbon emissions, economic growth, energy consumption, trade openness and Kyoto dummy variable. According to panel FMOLS estimation results, the coefficients of the real GDP is positive and statistically significant, but the coefficients of the square of the real GDP is statistically insignificant. That is, the inverted-U shaped relationship between economic growth and environmental pollution is invalid for selected EU countries over the period of 1991-2013. In addition, Kyoto Protocol has a negative impact on $\mathrm{CO}_{2}$ emissions for these countries. That is, Kyoto Protocol commitments for EU countries reduce carbon emissions. On the other hand, the coefficient of trade openness is insignificant.

These empirical findings provide some policy implications. Policy makers in EU countries should focus on growth models consistent with sustainable development goals. It is important to conduct projects that help to increase energy efficiency and energy saving and also increase the role of renewable energy from total energy use. In addition, it is essential to comply with the target of Kyoto Protocol reducing greenhouse gases to achieve sustainable development goals. It should be encouraged to use clean energy resources.

\section{REFERENCES}

Acaravci, A. and Ozturk, I. (2010). On the relationship between energy consumption, CO2 emissions and economic growth in Europe. Energy, 35(12): 5412-5420.

Apergis, N. and Payne, J.E. (2009). Energy consumption and economic growth in Central America: evidence from a panel cointegration and error correction model. Energy Econ.31:211-216.

Apergis, N. and Payne, J.E. (2010). The emissions, energy consumption, and growth nexus: Evidence from the common wealth of independent states. Energy Policy, 38: 650655. 
Bozkurt, C., Akan, Y., \& Okumus, I. (2016). Environmental Kuznets Curve Hypothesis In Bricts: The Role Of Tourism. Varazdin: Varazdin Development and Entrepreneurship Agency (VADEA). Retrieved from https://search.proquest.com/docview/1854280669?accountid $=15958$

Bölük, G., Mert, M. (2014). Fossil \& renewable energy consumption, GHGs (greenhouse gases) and economic growth: Evidence from a panel of EU (European Union) countries. Energy, 74(2014), 439-446.

Chen, W. (2007). Economic Growth and the Environment in China. Annual Conference for Development. Retrieved from http://www.policyinnovations.org/ideas/policy_library/ data/01447/_res/id=sa_File1/paper.pdf

Coondoo, D. and Dinda, S. (2002). Causality between income and emissions: a country group-specific econometric analysis. Ecological Economics, 40: 351-67.

Grossmann, G. M. and Krueger, A. B. (1991). Environmental impact of a North American free trade agreement. NBER Working Paper 3914.

Halicioglu, F. (2009). An econometric study of CO2 emissions, energy consumption, income and foreign trade in Turkey. Energy Policy, 37(3), 1156-1164.

Hunger, J. D., Wheelen, T. L. (2007) Essential of Strategic Management, Prentice Hall, Upper Saddle River, New Jersey, pp. 20-21.

Kuznets, S. (1955) Economic Growth and Income Inequality, The American Economic Review, 45(1), 1-28.

Kyoto Protocol 1997. United Nations framework convention on climate change [online], [cited 02 June 2019]. Available from Internet: http://unfccc.int/kyoto_protocol/items/2830.php

Lapinskiene, G., Tvaronaviciene, M., \& Vaitkus, P. (2014). Greenhouse Gases Emissions and Economic Growth-Evidence Substantiating The Presence of Environmental Kuznets Curve in The EU. Technological and Economic Development of Economy, 20(1), 65-78.

Luzzati, T. and Orsini, M. (2009). Investigating the energy-environmental Kuznets curve. Energy, 34(3): 291-300.

Ozturk, I. and Acaravci, A. (2010). CO2 emissions, energy consumption and economic growth in Turkey. Renewable and Sustainable Energy Reviews, 14(9): 3220-3225.

Ozturk, I. and Salah Uddin, G. (2012). Causality among carbon emissions, energy consumption and growth in India. Ekonomska istrazivanja, 25(3), 752-775.

Panayotou, T. (1993). Empirical Tests and Policy Analysis of Environmental Degradation at Different Stages of Economic Development. World Employment Programme Research, Working Paper.

Pao, H.T. and Tsai, C.H. (2010). CO2 emissions, energy consumption and economic growth. Energy Policy, 38(12): 7850-7860.

Richmond, A. K. and Kaufmann, R. K. (2006). Is there a turning point in the relationship between income and energy use and/or carbon emissions. Ecol. Econ. 56: 176-189.

Soytas, U., Sari, U. and Ewing, B.T. (2007). Energy consumption, income and carbon emissions in the United States. Ecological Economics, 62, 482-489.

Sterpu, M., Soava, G., \& Mehedintu, A. (2018). Impact of Economic Growth and Energy Consumption on Greenhouse Gas Emissions: Testing Environmental Curves Hypotheses on EU Countries. Sustainability 2018(10), 3327.

Sun, J.W. (1999). The nature of CO2 emission Kuznets curve. Energy Policy, 27, 691-694.

Zhang, X.P. and Cheng, X.M. (2009). Energy consumption, carbon emissions and economic growth in China. Ecological Economics, 68, 27062712. 